Bull. Mater. Sci., Vol. 17, No. 6, November 1994, pp. 671-684. (C) Printed in India.

\title{
Metallurgical aspects of corrosion
}

\author{
K BALAKRISHNAN \\ Central Electrochemical Research Institute, Karaikudi 623006 , India
}

\begin{abstract}
Metallurgical properties have strong effects on corrosion. The paper discusses and reviews the work done at CECRI on the metallurgical aspects of corrosion of some industrially important alloys like steel and aluminium alloy weldments, stainless maraging steel and prestressing steel. The corrosion control methods for the above materials are also reviewed.
\end{abstract}

Keywords. Weldments; corrosion; maraging steel; heat treatment; prestressing steel; shot peening.

\section{Introduction}

Metallurgical properties have strong effects on corrosion. The strength of the materials is increased by addition of alloying elements, heat treatments and other techniques. A major constraint for these techniques is increased susceptibility to stress corrosion cracking above certain strength levels. Many unexpected catastrophic failures have occurred due to stress-environment interactions. Knowledge of the relation between stress, mechanical properties, environments and stress corrosion resistance is critical to the proper application of many materials in various industrial sectors. Many of the mechanical properties and the corrosion resistance of a material can be related to its heat treatment. Welding affects the metallurgical properties and corrosion of the weldment. Metallurgical aspects of some important alloys are carried out at the Central Electrochemical Research Institute (CECRI), Karaikudi and this paper discusses and reviews the following metallurgical aspects of corrosion: (i) corrosion of steel and aluminium alloy weldments, (ii) effect of heat treatment on the corrosion behaviour of stainless maraging steel and (iii) effect of shot peening on the stress corrosion resistance of prestressing steel.

\section{Corrosion of steel weldments}

Welding causes inhomogeneities. Weld metal may not have the same composition and microstructure as the parent metal and the surface of the weld metal is generally rough. Residual stresses will be introduced in the weld because welding involves localized heating and cooling. Weld metal also has higher hardness and strength levels than the parent metal.

The difference in chemical composition, surface conditions, microstructure and mechanical stresses in the weldments make the corrosion behaviour of the weld different from that of the parent metal. If the composition of the weld metal differs from that of the parent metal, galvanic corrosion occurs. Severe attack on the weld metal will occur if the weld metal is anodic with respect to the parent metal. This is due to the small area of the anode compared with the area of the cathode. If 
the weld metal is cathodic with respect to the parent metal, the corrosion problem is less serious because the attack is distributed over the large anodic area. There have been reports of corrosion rates of up to $10 \mathrm{~mm} / \mathrm{y}$ at steel welds (Uusitalo 1961). This severe corrosion was attributed to the differences in electrochemical potential between the weld metal and the parent metal. Weld metal tends to display a more strongly electronegative behaviour than the parent metal. The factors that are primarily responsible for the potential differences are composition, metallurgical processes and heat treatment.

Preferential weld metal corrosion has been observed in marine structures. In these structures, ASTM A36 steel was joined to API $2 \mathrm{H}$ steel by shielded metal arc welding (SMAW). Cathodic protection is given to the steel structures. However, pits are seen only on the weld metal. We have carried out general corrosion, pitting corrosion, galvanic corrosion, cathodic protection and field exposure studies at Tuticorin seawater to know the reasons for the preferential weld corrosion and also to prevent pitting corrosion on the welds (Balakrishnan et al 1991; Sozhan 1991).

\subsection{Materials and welding}

The chemical composition of the ASTM A36 steel, API 2H steel and E7018 weld metal is given in table 1 . A36 steel was joined to API $2 \mathrm{H}$ steel by shielded metal arc welding using $\mathrm{E} 7018$ supertherme welding electrode ranging in diameter from $3.15 \mathrm{~mm}$ to $4 \mathrm{~mm}$. The welding parameters are given in table 2 . The stress relief heat treatment for the weld metal specimens was carried out in the furnace at $600^{\circ} \mathrm{C}$ for $1 \mathrm{~h}$ after which the specimens were cooled in the furnace.

Table 1. Chemical composition of the weld metal and parent metals.

\begin{tabular}{lccccccccc}
\hline Steel & C & Mn & S & P & Si & Cu & Ni & Cr & Al \\
\hline A 36 & 0.15 & 1.17 & 0.018 & 0.013 & 0.11 & 0.042 & nil & 0.014 & 0.078 \\
API 2H & 0.23 & 1.17 & 0.010 & 0.011 & 0.18 & 0.110 & 0.23 & 0.016 & 0.043 \\
Weld metal & 0.07 & 1.03 & 0.021 & 0.010 & 0.33 & 0.046 & 0.068 & 0.030 & 0.035 \\
\hline
\end{tabular}

Table 2. Welding parameters.

\begin{tabular}{|c|c|c|c|c|c|}
\hline $\begin{array}{l}\text { Pass } \\
\text { no. }\end{array}$ & $\begin{array}{l}\text { Electrode } \\
\text { size }\end{array}$ & & Amp. & $\begin{array}{c}\text { Volts } \\
\text { (mm/min) }\end{array}$ & Travel speed \\
\hline 1 & $3 \cdot 15$ & $110-115$ & $24-25$ & $70-80$ & \\
\hline 2 & $3 \cdot 15$ & $125-130$ & $24-25$ & $45-50$ & \\
\hline 3 & $4 \cdot 0$ & $155-165$ & $24-25$ & $45-55$ & \\
\hline 4 & $4 \cdot 0$ & $155-165$ & $24-25$ & $60-80$ & \\
\hline 5 & $4 \cdot 0$ & $155-165$ & $24-25$ & $60-80$ & \\
\hline 6 & $4 \cdot 0$ & $155-165$ & $24-25$ & $60-80$ & \\
\hline 7 & 4.0 & $155-165$ & $24-25$ & $60-75$ & \\
\hline \multicolumn{6}{|c|}{ Back gauge and ground } \\
\hline 8 & 4.0 & $170-185$ & $24-25$ & $50-70$ & \\
\hline 9 & 4.0 & $170-185$ & $24-25$ & $50-70$ & \\
\hline
\end{tabular}




\subsection{General corrosion}

2.2a Polarization studies: The general corrosion behaviour of the weldments in $3.5 \% \mathrm{NaCl}$ solution and synthetic seawater was determined through polarization studies and the results are given in tables 3 and 4 respectively. It can be seen from the tables that the corrosion rate of the weld metal is higher than both the parent metals. Postweld heat treatment improves the corrosion resistance. It can be seen from table 4 that the corrosion rates in synthetic seawater for API $2 \mathrm{H}$ steel and A36 steel are $8.4 \mu \mathrm{A} / \mathrm{cm}^{2}$ and $9 \mu \mathrm{A} / \mathrm{cm}^{2}$, respectively while for the weld metal, the corrosion rate is $15 \mu \mathrm{A} / \mathrm{cm}^{2}$. Thus, the weld corrodes two times higher than the parent metals. After post-weld heat treatment, the corrosion rate of the weld is $7 \mu \mathrm{A} / \mathrm{cm}^{2}$ which is equivalent to the corrosion rate of the parent metals.

$2.2 b$ Electrochemical impedance measurements: Impedance measurements were carried out on the weld metal, parent metals and PWHT metal in synthetic seawater at the corrosion potential in the frequency range of $10 \mathrm{kHz}$ to $10 \mathrm{mHz}$ using the Model M 378 impedance measurement system, EG and G PAR, USA. Figure 1 shows the impedance diagrams for the weld metal, PWHT metal and the parent metals. The charge transfer resistance values, estimated from the impedance diagrams are given in table 5. The charger transfer resistance is inversely proportional to the corrosion rate. The weld metal has low $R_{\mathrm{t}}$ value than the parent metals, indicating higher corrosion rates than the parent metals. Postweld heat treatment significantly improves the corrosion resistance.

\subsection{Pitting corrosion}

The resistance of the weldments to pitting corrosion was evaluated in $0.04 \mathrm{~N}$ $\mathrm{NaOH}+600 \mathrm{ppm}$ chloride and synthetic seawater $+10^{-5} \mathrm{M} \mathrm{Na}_{2} \mathrm{~S}$ through potentiostatic

Table 3. Polarization data in $3.5 \%$ $\mathrm{NaCl}$ solution.

\begin{tabular}{lc}
\hline Metal & $\begin{array}{c}\text { Corrosion current } \\
\left(\mu \mathrm{A} / \mathrm{cm}^{2}\right)\end{array}$ \\
\hline API 2H steel & 8.0 \\
A36 steel & 11.0 \\
Weld metal & 20.0 \\
PWHT & 6.0 \\
\hline
\end{tabular}

Table 4. Polarization data in synthetic seawater.

\begin{tabular}{lc}
\hline Metal & $\begin{array}{c}\text { Corrosion current } \\
\left(\mu \mathrm{A} / \mathrm{cm}^{2}\right)\end{array}$ \\
\hline API 2H steel & 8.4 \\
A36 steel & 9.0 \\
Weld metal & 15.0 \\
PWHT & 7.0 \\
Welding rod & 18.0 \\
\hline
\end{tabular}




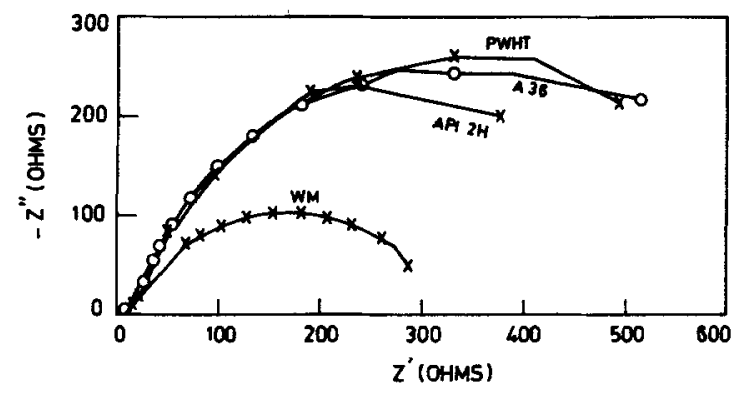

Figure 1. Impedance diagram in synthetic seawater at the corrosion potential.

Table 5. The charge transfer resistance values estimated from the impedance measurements.

\begin{tabular}{lc}
\hline Metal & $\begin{array}{c}\text { Charge transfer } \\
\text { resistance value } \\
\left(\text { Rt. } \text { cm }^{2}\right)\end{array}$ \\
\hline API 2H steel & 487 \\
A36 steel & 667 \\
Weld metal & 300 \\
PWHT metal & 645 \\
\hline
\end{tabular}

polarization studies. The pitting potentials estimated from polarization curves in these solutions are given in tables 6 and 7. The weld metal has lower pitting corrosion resistance than the parent metals. PWHT improves the pitting corrosion resistance of weld metal.

\subsection{Galvanic corrosion}

The galvanic corrosion currents were measured for (i) weld metal vs A36 steel, (ii) weld metal vs API $2 \mathrm{H}$ steel, (iii) PWHT vs A36 steel, (iv) PWHT vs API $2 \mathrm{H}$ steel, (v) weld with $\mathrm{Cu}$ and $\mathrm{Ni}$ vs $\mathrm{A36}$ steel and (vi) weld with $\mathrm{Cu}$ and $\mathrm{Ni}$ vs API $2 \mathrm{H}$ steel couples in 3.5\% $\mathrm{NaCl}$ solution and synthetic seawater (Sozhan 1991). The galvanic currents measured for the above couples after $48 \mathrm{~h}$ of exposure are given in table 8. It can be seen from the table that the unalloyed weld is always anodic with respect to both the parent metals. At the end of $48 \mathrm{~h}$, the galvanic current density was the highest for the weld-API $2 \mathrm{H}$ couple $\left(11.8 \mu \mathrm{A} / \mathrm{cm}^{2}\right)$ and lowest for the weld-A36 couple $\left(4.8 \mu \mathrm{A} / \mathrm{cm}^{2}\right)$ in synthetic seawater. Thus, the galvanic current density for the weld-API $2 \mathrm{H}$ couple is 3 times higher than the weld-A36 couple. The higher galvanic currents measured in weld-API $2 \mathrm{H}$ couple is due to the difference in the composition of the weld metal and API $2 \mathrm{H}$ steel. The weld metal contains higher silicon content $(0.33 \%)$ than API $2 \mathrm{H}$ steel $(0.18 \%)$. The metals with $\mathrm{Si}$ content $>0.25 \%$ behave as most unnoble metals (Parkinson et al 1989). Moreover, API $2 \mathrm{H}$ steel contains more $\mathrm{Cu}$ and $\mathrm{Ni}$ than the weld metal 
which make it more nobler than the weld metal. Hence, the weld-API $2 \mathrm{H}$ couple has higher galvanic current density than the weld-A36 couple.

The galvanic currents measured for the weld coupled to A36 steel and API $2 \mathrm{H}$ steel are for an area ratio of $1: 1$. But, in the existing structures, the actual area ratio between the weld metal and parent metals is very much higher than $1: 1$, and hence higher galvanic currents may be expected between the weld and the parent metal couples.

Weld. metal corrosion in ships was attributed to the galvanic corrosion between the weld metal and parent metal (Uusitalo 1966). Premature failure of A53 steel pipe by weld corrosion in the process stream was observed (Liening 1986). This was due to the galvanic corrosion between E 6010 weld metal and A53 steel pipe, and weld was anodic with respect to the steel pipe.

Table 6. Pitting corrosion data in $0.04 \mathrm{~N} \mathrm{NaOH}+600$ ppm chloride.

\begin{tabular}{lc}
\hline Metal & $\begin{array}{c}\text { Pitting potential } \\
\text { (mV vs SCE) }\end{array}$ \\
\hline API 2H steel & +245 \\
A36 steel & +110 \\
Weld metal & +95 \\
\hline
\end{tabular}

Table 7. Pitting corrosion data in synthetic sea water $+10^{-5} \mathrm{M}$ Na2S.

\begin{tabular}{lc}
\hline Metal & $\begin{array}{c}\text { Pitting potential } \\
\text { (mV vs SCE) }\end{array}$ \\
\hline API 2H steel & -814 \\
A36 steel & -773 \\
Weld metal & -848 \\
PWHT & -805 \\
\hline
\end{tabular}

Table 8. Galvanic current measurements after $48 \mathrm{~h}$ of exposure in $3.5 \% \mathrm{NaCl}$ and synthetic seawater.

\begin{tabular}{lccc}
\hline & \multicolumn{2}{c}{ Galvanic currents $\left(\mu \mathrm{A} / \mathrm{cm}^{2}\right)$} & \\
\cline { 2 - 3 } & $3.5 \% \mathrm{NaCl}$ & $\begin{array}{c}\text { Synthetic } \\
\text { seawater }\end{array}$ & Remarks \\
Galvanic couple & -4.2 & -4.8 & Weld is anodic \\
\hline Weld vs A36 steel & -10.9 & -11.8 & Weld is anodic \\
Weld vs API2H steel & +2.9 & +0.8 & Weld is cathodic \\
PHWT vs A36 steel & -1.6 & -2.3 & Weld is anodic \\
PHWT vs API2H steel & +4.0 & +3.6 & Weld is cathodic \\
Welding electrode with Cu & & -1.4 & Weld is anodic \\
and Ni vs A36 steel & -1.0 & & \\
Welding electrode vs API \\
2H steel with Cu and $\mathrm{Ni}$
\end{tabular}


PWHT improves the galvanic corrosion resistance of the weld vs A36 and weld vs API $2 \mathrm{H}$ steel couples. The weld corrosion can be eliminated by using a suitably balanced electrode material.

Matching composition electrodes are preferred for the highest corrosion resistance. If unalloyed weld electrodes are used, the 'weld itself is corroded preferentially (Uusitalo 1966). Alloying elements are added to the coated electrode as a means of modifying or controlling the chemistry of the weld metal. Weld electrodes with increased copper or nickel were more resistant to localized corrosion (Garner et al 1989). $1.1 \% \mathrm{Cu}$ and $0.72 \% \mathrm{Ni}$ were added to the $\mathrm{E} 7018$ welding electrode and the galvanic corrosion resistance were made. In welding electrode with $\mathrm{Cu}$ and $\mathrm{Ni}$ vs A36 couple, weld is cathodic. In general, it would be preferable for the weld metal to be somewhat cathodic because of its relatively small area as compared with parent metal.

\subsection{Field exposure studies}

Weldments of size $6^{\prime} \times 4^{\prime}$ with the weld at the centre were exposed to a depth of $3 \mathrm{~m}$ inside the sea at Offshore Platform and Marine Electrochemistry Centre (Unit of CECRI, Karaikudi). Figure 2 shows the surface appearance of the welded sample after 1 month of exposure. Corrosion occurs first on the weld zone. Barnacles are not attached to the weld samples during this test period. After 3 months of exposure, attachment of barnacles are observed on the welded samples. The average number of barnacles attached on the weld zone and the parent metals are given in table 9. Since the weld metal is rough, a large number of barnacles are attached to the weld zone as compared to the parent metals. After 6 months of exposure, the specimens showed preferential weld zone corrosion (figure 3 ).

\subsection{Cathodic protection}

The most common method of preventing corrosion of welds on offshore platforms is cathodic protection. Pitting corrosion $>5 \mathrm{~mm}$ in depth was found in welds on some north sea platforms when cathodic protection was inadequate (Smart 1980). On offshore steel platforms, node welds are joints of high stress because stress concentration occurs due to the complex geometry at these locations. Therefore, adequate cathodic protection needs to be given to the node welds; insufficient protection leads to pitting corrosion. However, over protection should not be given to the weldments because it affects the mechanical properties of the weld metal. Hydrogen enters into the metal during overprotection leading to hydrogen embrittlement (Hoar 1969; Saeuz et al 1986). Electrochemical impedance technique was used to optimize the cathodic protection potential for the shielded metal arc welded steel and post-weld heat treated (PWHT) steel in $3.5 \% \mathrm{NaCl}$ solution (Sozhan et al 1993). Impedance measurements were carried out at the corrosion potential and also at different constant cathodic potentials $(-730,-780,-800$, $-850,-900,-950$ and $-1000 \mathrm{mV}$ vs SCE) for the weld metal and PHWT metal in $3.5 \% \mathrm{NaCl}$ solution. A protection potential of $-950 \mathrm{mV}$ vs SCE is necessary to protect the welds whereas $-900 \mathrm{mV}$ vs SCE is sufficient to protect the post-weld heat treated metal. Immersion studies were also carried out in $3.5 \% \mathrm{NaCl}$ solution 


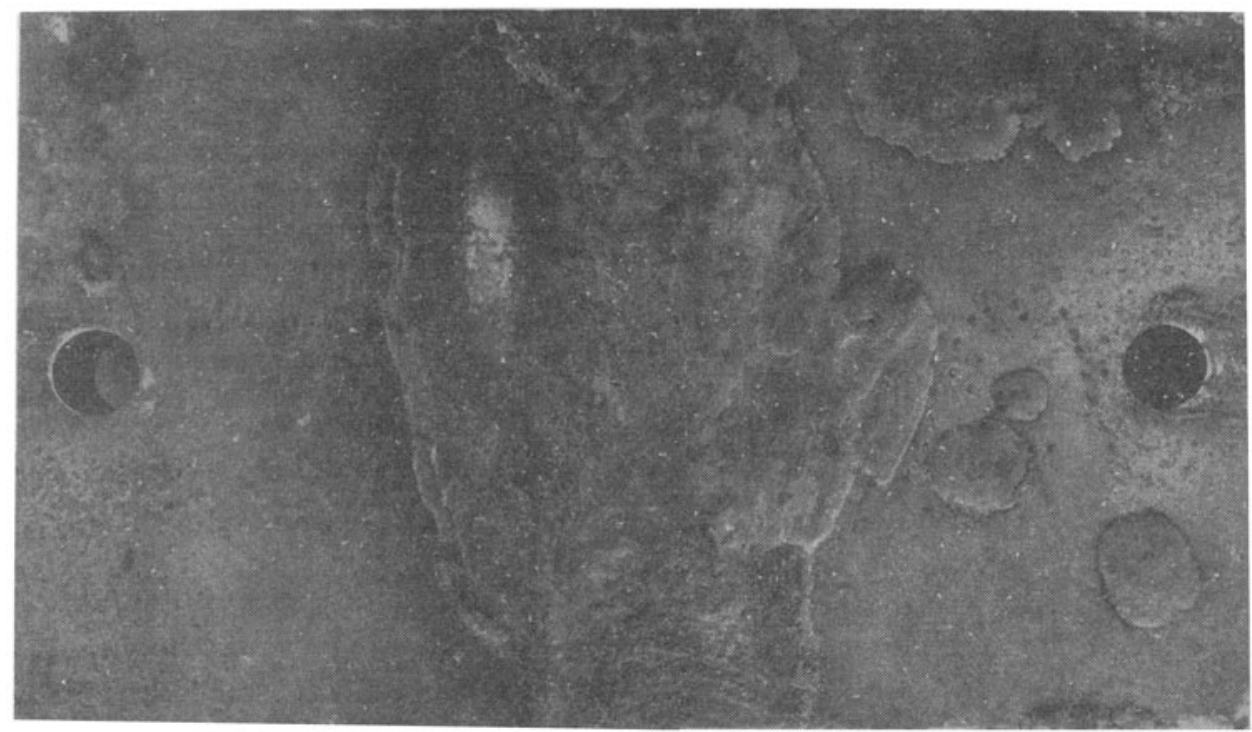

Figure 2. Corrosion products on the weld zone after one month of exposure at Tuticorin seawater.

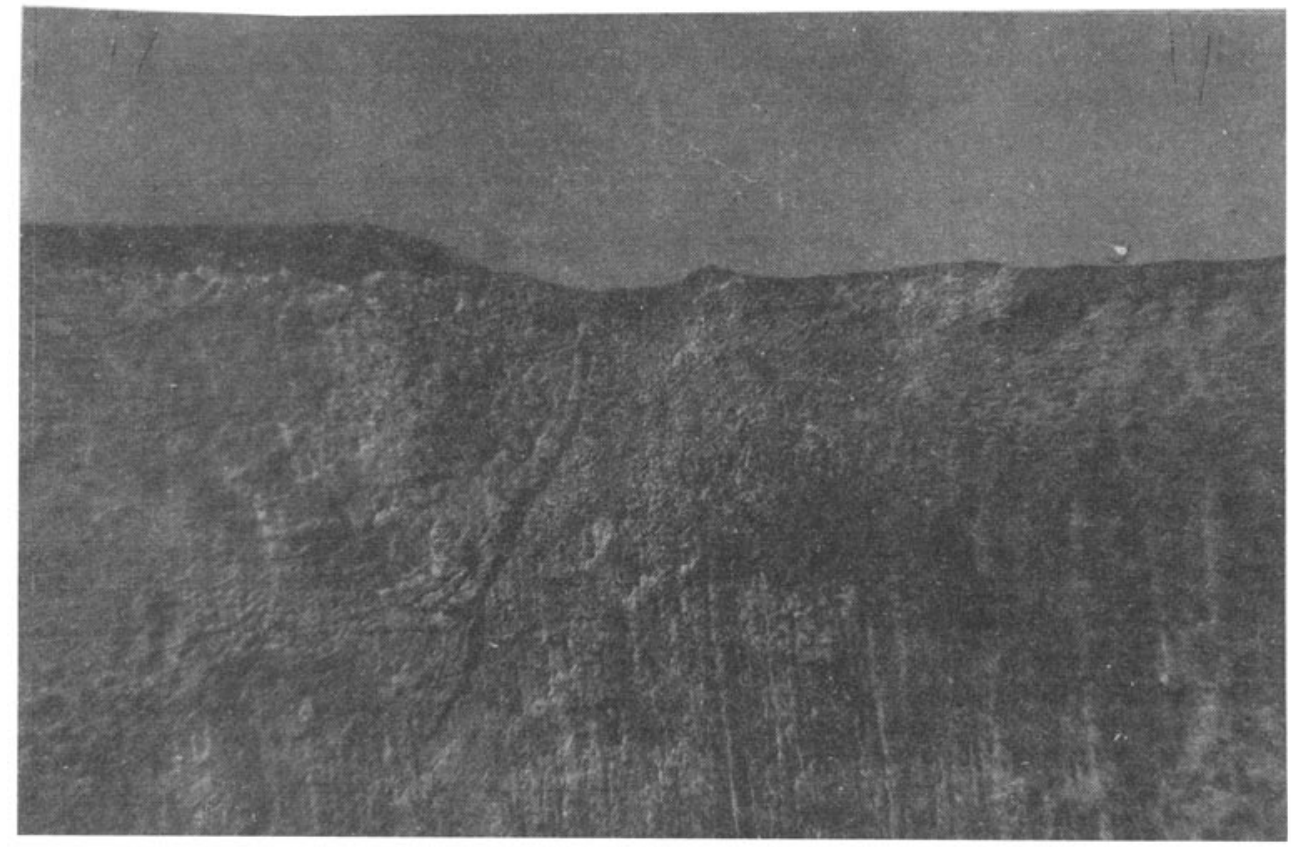

Figure 3. Weld zone corrosion after six month of exposure at Tuticorin seawater. 
on SMA and PWHT welds for $120 \mathrm{~h}$ at various constant cathodic potentials to compare the results of impedance measurements. Weight loss data show that the corrosion rate for weld metal is minimal at $-950 \mathrm{mV}$ vs SCE, whereas for the PWHT it is minimal at $-900 \mathrm{mV}$ vs SCE. The results of the weight loss data correlate well with results from the impedance technique.

Pitting corrosion has been observed on the platform joints in North sea maintained at $-850 \mathrm{mV}$ vs $\mathrm{Ag} / \mathrm{AgCl}$ (Du $\mathrm{Yu}$ et al 1989). Node welds are partly shielded by many intersecting structural members with areas of higher than average surface density. Hence, these node welds are inherently the most difficult to protect (Smart 1980). The pit observed on the node weld of the North sea platform protected by cathodic protection is attributed to the insufficient cathodic protection at these node welds. Now the platform is adequately protected. Analysis of the pipeline failures reported to the US Department of Transportation for the period from 1970 to 1973 showed that $76 \%$ of the external corrosion failures were attributed to the pitting corrosion. Potentials more negative than $-950 \mathrm{mV}$ vs $\mathrm{Cu} / \mathrm{CuSO}_{4}$ are required to prevent pits (Toncre 1989). Polarized potentials of $-1000 \mathrm{mV}$ vs $\mathrm{Cu} / \mathrm{CuSO}_{4}(-950 \mathrm{mV}$ vs $\mathrm{Ag} / \mathrm{AgCl}$ ) are necessary to protect the structures when complete corrosion prevention is desired (Gummow 1986). Investigations at CECRI on the welded sample reveal that protection potential of $-950 \mathrm{mV}$ vs SCE $(-970 \mathrm{mV}$ vs $\mathrm{Ag} / \mathrm{AgCl})$ is required to protect the welds.

\section{Corrosion of 7020 aluminium alloy weldments}

Aluminium alloy is used for aerospace applications. Welding is done to fabricate tanks. The general and stress corrosion behaviour of AFNOR 7020 aluminium alloy sheet in T6 temper welded using (i) AG $4.5 \mathrm{Mn}$ filler metal, (ii) AG $4 \mathrm{Z2}$ filler

Table 9. Average number of barnacles attached to the weld metal and the parent metals.

\begin{tabular}{lc}
\hline Metal & $\begin{array}{c}\text { Average number of } \\
\text { barnacles/dm }\end{array}$ \\
\hline API 2H steel & 155 \\
A36 steel & 123 \\
Weld metal & 210 \\
\hline
\end{tabular}

Table 10. Corrosion rates of the 7020 parent metal and welds after 30 days of immersion in liquid $\mathrm{N}_{2} \mathrm{O}_{4}$.

\begin{tabular}{lc}
\hline $\begin{array}{l}\text { Parent metal/weld } \\
\text { with filler metal }\end{array}$ & $\begin{array}{c}\text { Corrosion rate } \\
\text { (mmpy) }\end{array}$ \\
\hline Parent metal & 0.004 \\
AG $4.5 \mathrm{Mn}$ & 0.006 \\
AG 4Z2 & 0.004 \\
AG 5 & 0.040 \\
\hline
\end{tabular}


metal and (iii) AG 5 filler metal were determined in liquid $\mathrm{N}_{2} \mathrm{O}_{4}$ to select the best filler metal for fabrication of tanks to handle $\mathrm{N}_{2} \mathrm{O}_{4}$ (Balakrishnan et al 1994).

\subsection{General corrosion}

The general corrosion resistance of these weldments was evaluated through immersion studies for 30 days and electrochemical impedance measurements. The corrosion rates after 30 days of immersion in liquid $\mathrm{N}_{2} \mathrm{O}_{4}$ are given in table 10. The results show that 7020 welded with AG4Z2 has higher general corrosion resistance compared to other filler metals. The corrosion rate of this AG4Z2 weld is similar to the parent metal. The corrosion rate of other filler metal AG 4.5 $\mathrm{Mn}$ is about two times higher than the parent metal, and another AG 5 filler metal corrodes ten times more than the parent metal.

The electrochemical impedance measurements were carried out on the parent metal as well as on the welded sheets in $\mathrm{N}_{2} \mathrm{O}_{4}$ liquid using the frequency response analyzer (Model 1174, Solotron, UK) and the electrochemical interface (Model 1174 , Solotron) over a frequency range of $1 \mathrm{~Hz}$ to $10 \mathrm{kHz}$. The impedance diagrams are given in figure 4. The alloy welded with AG5 filler wire behaves differently from that of other samples. The depressed semi circle of AG 5 filler wire indicates the presence of a charge transfer reaction mostly corresponding to the dissolution of the alloy. In the case of parent metal and other two filler metals, resistive and diffusion control behaviour occur due to the presence of passive film.

\subsection{Stress corrosion}

The stress corrosion behaviour of the parent metal and the welded sheets was evaluated in liquid $\mathrm{N}_{2} \mathrm{O}_{4}$ by short term and long term SCC tests.

3.2a Short term SCC tests: Constant load tests were used. The stress was applied by means of spring loaded test set-up. Stress applied was $18.1 \mathrm{~kg} / \mathrm{mm}^{2}$. The stressed

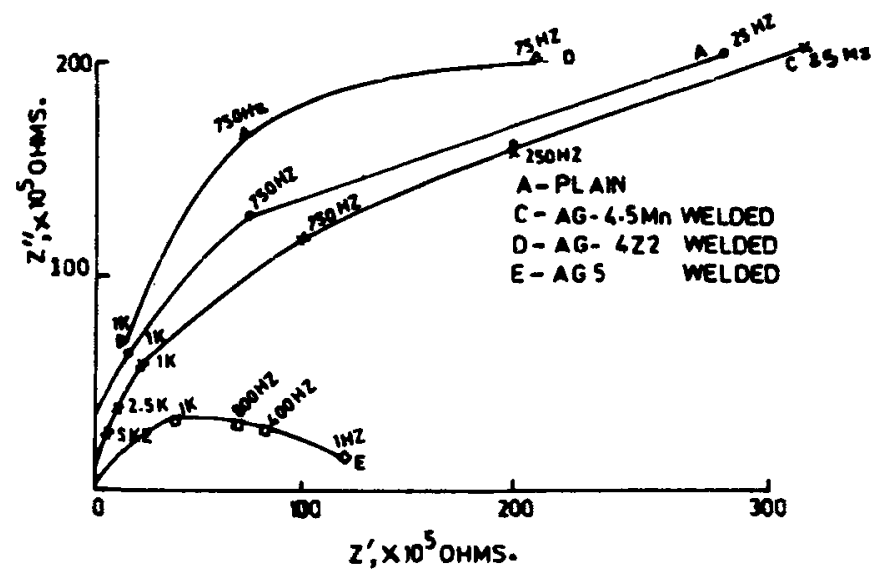

Figure 4. Impedance diagram for the parent metal and welded alloys in liquid $\mathrm{N}_{2} \mathrm{O}_{4}$. 
samples were exposed to liquid $\mathrm{N}_{2} \mathrm{O}_{4}$ for $6 \mathrm{~h}$. The parent metal and the welded specimens were examined using optical microscope after $6 \mathrm{~h}$ of exposure. Microcracks were observed near the weld line-plate joint with AG4.5Mn and AG5 filler metals. No cracks were observed in AG4Z2 filler metal and parent metal. The results of the short term SCC tests show that the welded sheet with AG4Z2 filler metal is resistant to $\mathrm{SCC}$ in liquid $\mathrm{N}_{2} \mathrm{O}_{4}$ at the stress level of $18 \cdot 1 \mathrm{~kg} / \mathrm{mm}^{2}$.

3.2b Long term SCC test: Bent beam technique (four-point loading) was used to apply stress. $8.2 \mathrm{~kg} / \mathrm{mm}^{2}$ stress was applied to the parent metal and the welded specimens and then they were exposed to liquid $\mathrm{N}_{2} \mathrm{O}_{4}$ for 100 days. The specimens were examined using optical microscope after 100 days of exposure. No stress corrosion cracks were seen on the welded specimens with three filler metals, and the parent metal during this period of testing. The general and stress corrosion studies in liquid $\mathrm{N}_{2} \mathrm{O}_{4}$ reveal that alloy welded with $\mathrm{AG} 4 \mathrm{Z} 2$ filler metal has corrosion resistance than the other AG4.5 Mn and AG5 filler metals.

\section{Effect of heat treatment on corrosion of stainless maraging steel}

\subsection{Stainless maraging steel}

The corrosion behaviour of the stainless maraging steel depends upon the composition and heat treatment. The general corrosion resistance is maximum when this steel is in solution heat treated condition. Aging, depending on the temperature, decreases the corrosion resistance of stainless maraging steel considerably. The steel aged at lower temperature has better corrosion resistance than the steel aged at higher temperature.

The stress corrosion cracking resistance varies with aging. In general, those environments which produce SCC in other high strength steels are also found to produce cracking in stainless maraging steels. Overaging improves the stress corrosion resistance (McDarmaid 1982). Coatings or cathodic protection can be given to protect the stainless maraging steel in marine environments (Papier 1988). The general pitting and stress corrosion behaviour of stainless maraging steel were evaluated in chloride environments at CECRI (Balakrishnan et al 1994).

\subsection{Material and heat treatment}

The stainless maraging steel used in this study was $0.72 \mathrm{~mm}$ cold rolled sheet. The chemical composition of this steel is given in table 11 . The material was received in the solution heat treated condition (solution treated at $980^{\circ} \mathrm{C}$ for $30 \mathrm{~min}$ and air cooled). The solution treated steel was aged at $450^{\circ} \mathrm{C}$ for $4 \mathrm{~h}$ (underaged), $450^{\circ} \mathrm{C}$ for $5 \mathrm{~h}$ (peakaged) and for $7 \mathrm{~h}$ (overaged). The mechanical properties are given in table 12.

\subsection{General corrosion}

The general corrosion behaviour of stainless maraging steels in underaged and 
overaged conditions were determined in $3.5 \% \mathrm{NaCl}$ solution through polarization and impedance measurements. The results of the studies are given in table 13. It can be seen from the table that overaged sample has higher general corrosion resistance than the underaged sample.

\subsection{Pitting corrosion}

The pitting corrosion resistance of underaged, peakaged and overaged stainless maraging steel was evaluated in $0.04 \mathrm{~N} \mathrm{NaOH}$ containing $1000 \mathrm{ppm}$ chloride using potentiodynamic polarization studies. The pitting corrosion data are given in table 14. The overaged sample has higher pitting corrosion resistance than the underaged and peakaged samples. Electropolishing in $\mathrm{H}_{3} \mathrm{PO}_{4}+\mathrm{H}_{2} \mathrm{SO}_{4}+\mathrm{CrO}_{3}$ solution improves the corrosion resistance.

\subsection{Stress corrosion}

Stress corrosion tests were carried out on underaged and overaged specimens in $5 \% \mathrm{NaCl}$ solution. The stress applied was $80 \%$ of proof stress. The results of SCC studies are given in table 15 . It can be seen from the table that overaging

Table 11. Chemical composition of stainless maraging steel.

\begin{tabular}{lccccccccc}
\hline & $\mathrm{Cr}$ & $\mathrm{Co}$ & $\mathrm{Ni}$ & $\mathrm{Mo}$ & $\mathrm{Ti}$ & $\mathrm{Al}$ & $\mathrm{Si}$ & $\mathrm{C}$ & $\mathrm{Fe}$ \\
\hline Element\% & 12 & 12 & 4 & 4 & 0.5 & 0.3 & 0.1 & 0.02 & Bal. \\
\hline
\end{tabular}

Table 12. Mechanical properties.

\begin{tabular}{lcccc}
\hline $\begin{array}{l}\text { Heat } \\
\text { treatment }\end{array}$ & $\begin{array}{c}0.2 \% \text { Yield } \\
\text { strength } \\
\left(\mathrm{kg} / \mathrm{mm}^{2}\right)\end{array}$ & $\begin{array}{c}\text { Ultimate tensile } \\
\text { strength } \\
\left(\mathrm{kg} / \mathrm{mm}^{2}\right)\end{array}$ & $\begin{array}{c}\text { Elongation } \\
(\%)\end{array}$ & $\begin{array}{c}\text { Hardness } \\
(\mathrm{VPN})\end{array}$ \\
\hline $450^{\circ} \mathrm{C} / 4 \mathrm{~h}$ & 138.4 & 145.7 & 8.4 & $485-495$ \\
$450^{\circ} \mathrm{C} / 7 \mathrm{~h}$ & 132.6 & 141.5 & 9.2 & $480-500$ \\
\hline
\end{tabular}

Table 13. Effect of heat treatment on the general corrosion behaviour in $3.5 \%$ $\mathrm{NaCl}$ solution.

\begin{tabular}{|c|c|c|c|}
\hline $\begin{array}{l}\text { Type of heat } \\
\text { treatment }\end{array}$ & $\begin{array}{l}\text { Heat treatment } \\
\text { condition }\end{array}$ & $\begin{array}{l}\text { Corrosion current by } \\
\text { polarization technique } \\
\qquad\left(\mu \mathrm{A} / \mathrm{cm}^{2}\right)\end{array}$ & $\begin{array}{c}R_{c t,}\left(\mathrm{~K} \text { ohm } \mathrm{cm}^{2}\right) \\
\text { by impedance } \\
\text { technique }\end{array}$ \\
\hline $\begin{array}{l}\text { Solution } \\
\text { annealed }\end{array}$ & - & 0.15 & $>30$ \\
\hline Underaged & $450^{\circ} \mathrm{C}, 4 \mathrm{~h}$ & 3 & $3 \cdot 1$ \\
\hline Peakaged & $450^{\circ} \mathrm{C}, 5 \mathrm{~h}$ & 3.3 & $2 \cdot 2$ \\
\hline Overaged & $450^{\circ} \mathrm{C}, 7 \mathrm{~h}$ & 2 & $4 \cdot 3$ \\
\hline
\end{tabular}


Table 14. Pitting corrosion behaviour of stainless maraging steel in $0.04 \mathrm{~N} \mathrm{NaOH}+1000$ ppm chloride.

\begin{tabular}{lccc}
\hline $\begin{array}{l}\text { Type of heat } \\
\text { treatment }\end{array}$ & $\begin{array}{c}\text { Heat treatment } \\
\text { condition }\end{array}$ & $\begin{array}{c}\text { Pitting potential } \\
(\mathrm{mV} \text { vs SCE) }\end{array}$ & $\begin{array}{c}\text { Protection potential } \\
(\mathrm{mV} \text { vs SCE) }\end{array}$ \\
\hline Mechanical polishing & & & \\
Underaged & $450^{\circ} \mathrm{C}, 4 \mathrm{~h}$ & +50 & -75 \\
Overaged & $450^{\circ} \mathrm{C}, 7 \mathrm{~h}$ & +250 & 0 \\
Electropolishing & & & \\
$\begin{array}{l}\text { Underaged } \\
\text { Peakaged }\end{array}$ & $450^{\circ} \mathrm{C}, 4 \mathrm{~h}$ & +650 & +650 \\
Overaged & $450^{\circ} \mathrm{C}, 5 \mathrm{~h}$ & +660 & +660 \\
& $450^{\circ} \mathrm{C}, 7 \mathrm{~h}$ & +750 & +750 \\
\hline
\end{tabular}

Table 15. Constant load SCC test data.

\begin{tabular}{lc}
\hline Aging & $\begin{array}{c}\text { Time to failure } \\
\text { (h) }\end{array}$ \\
\hline $\begin{array}{l}\text { Underaged }\left(450^{\circ} \mathrm{C} / 4 \mathrm{~h}\right) \\
\text { Overaged }\left(450^{\circ} \mathrm{C} / \mathrm{h}\right)\end{array}$ & $10-13$ \\
\hline
\end{tabular}

Stress: $80 \%$ of proof stress; medium: $5 \% \mathrm{NaCl}$ solution.

significantly improves the stress corrosion resistance. The overaged sample has thirty times higher stress corrosion resistance than the underaged sample.

\section{Effect of shot peening on stress corrosion}

Prestressing steels are vulnerable to stress corrosion cracking (SCC) since they are held under permanent tension while in service. Many premature failures of prestressed concrete bridges, tanks and ground anchors are due to SCC of prestressing steel wires (Cornet 1964; Szialand 1969; Little John 1986). In recent years, serious corrosion failures of prestressed concrete structures have occurred. For example, the southern outer roof of the Berlin Assembly Hall suddenly collapsed. The failure is attributed to hydrogen-induced stress corrosion cracking of prestressed steel (Isecke 1983).

The feasibility of introducing surface compressive stresses using shot peening to improve stress corrosion resistance of prestressing steel has not been examined so far. CECRI has studied the effect of controlled shot peening on the stress corrosion behaviour of prestressing steel in $20 \%$ ammonium thiocyanate solution (Rengaswamy et al 1991). According to FIP, this solution is the most convenient and reliable one for the study of hydrogen-induced SCC of prestressing steel (FIP Report 1980).

Figure 5 shows the percentage proof stress vs time-to-failure in 20\% ammonium thiocyanate solution. The threshold stress is increased from $20 \%$ to $30 \%$ for shot peened specimens. Under $80 \%$ proof stress, time-tomfailure is $197 \mathrm{~min}$ for shot peened specimens, whereas it is only $18 \mathrm{~min}$ for unpeened specimens. Thus, there is a ten-fold increase in time-to-failure due to shot peening. Shot peening introduces 


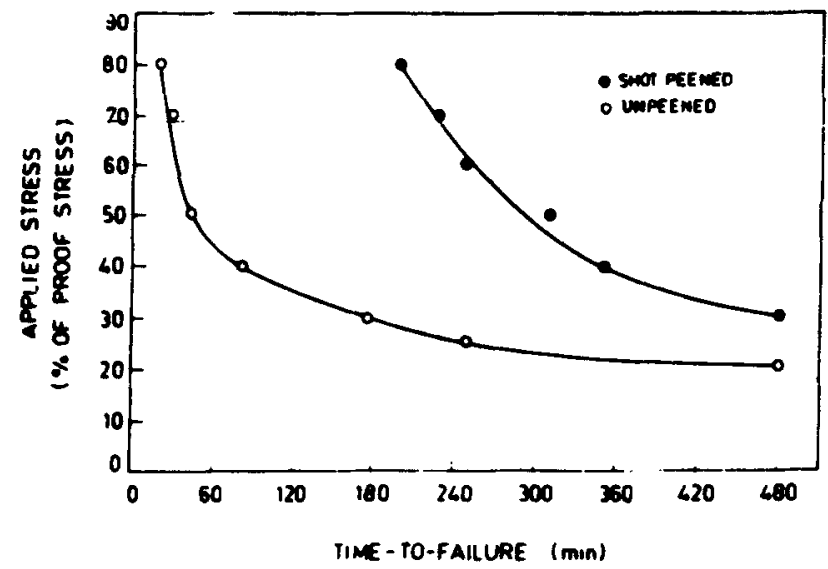

Figure 5. Applied stress vs time-to-failure data in $20 \%$ ammonium thiocyanate solution; $500 \mathrm{mV}$ cathodic.

surface compressive stresses, and removes notches and other surface defects responsible for stress considerations by producing small shallow dents on the surface (Metals Handbook 1982). The surface compressive stress induced by shot peening helps to lower the level of applied tensile stress at the surface because of the superimposition of internal stresses and external applied load (Hara 1989). Shot peening mainly helps to delay the initiation of the stress corrosion cracking process.

\section{Conclusions}

Welding affects the metallurgical properties of the weldment. This results in increased corrosion rate of the weld metal. Higher cathodic protection potential is required to prevent corrosion of weld metal. Post weld heat treatment significantly improves the corrosion resistance of weld metal. Weld electrode containing copper and nickel are more resistant to weld zone corrosion.

The general and stress corrosion studies on AFNOR 7020 aluminium alloy in T6 temper welded with AG4.5 Mn, AG4Z2 and AG5 filler metals in liquid $\mathrm{N}_{2} \mathrm{O}_{4}$ reveal that $\mathrm{AG} 4 \mathrm{Z} 2$ filler metal has higher corrosion resistance than other filler metals.

Overaging of stainless maraging steel improves the general, pitting and stress corrosion resistance in chloride solutions. Electropolishing in $\mathrm{H}_{3} \mathrm{PO}_{4}+\mathrm{H}_{2} \mathrm{SO}_{4}+\mathrm{CrO}_{3}$ solution improves the corrosion resistance of stainless maraging steel.

Controlled shot peening of prestressing steel significantly increases its stress corrosion resistance. The threshold stress is increased from 20 to $30 \%$.

\section{References}

Balakrishnan K et al 1991 CECRI Report on Pitting corrosion of steel welds in seawater Balakrishnan K, Marikkannu C, Ramu S, Balasrinivasan P and Murali K 1993 CECRI Report on development of surface coating to prevent stress corrosion failures of high strength special steels 
Balakrishnan K, Rengaswamy N S, Venkatachari G, Ramu S and Marikkannu C 1994 Corrosion Asia 94 Cornet I 1964 Mater. Prot. 390

Du Yu et al 1989 in Corrosion and corrosion control for offshore and marine construction (Pergamon Press)

FIP Report 1980 Report on prestressing steel: 5 SCC resistance for prestressing tendons (UK: FIP slough)

Garner A, Gilmour J B and Brigham R J 1989 Corrosion 89

Gummow R A 1986 Mater. Perform. 2516

Hara O P 1989 Corrosion Prev. Control 36163

Hoar T P 1969 Br. Corros. J. 246

Isecke B 1983 in Corrosion of reinforcement in concrete construction (ed) Alan P Crane (Ellis Horwood Ltd)

Liening E L 1986 in Trouble-shooting in industrial corrosion problems (ASTM STP 908)

Little John G S 1986 FIP State of the art report: Corrosion and corrosion protection of prestressed ground anchorages (Thomas Telford Ltd)

McDarmaid D S 1982 Br. Corros. J. 17112

Metals Handbook 1982 ASM 9th edn. p. 138

Parkinson L D, Malik L, Mitrovic-Scapanovic V and Brigham R J 1989 Can. Met. Quart. 28135

Papier J H 1988 in Maraging steels-Recent developments and applications (Arizona: The Minerals and Metals Society) p. 125

Rengaswamy N S, Ramu S, Govindarajan G and Balakrishnan K 1991 Corrosion Prev. Control 38101

Smart J S 1980 Mater. Pei,orm. 1941

Sozhan G 1991 Corrosion behaviour of steel welds in sea water, ME Thesis, REC, Trichy

Sozhan G, Ramu S, Krishnan K N and Balakrishnan K 1993 Tenth European Corrosion Congress, Barcelona, Spain

Szialand 1969 Am. Concr. Inst. J. 6642

Toncre A C 1989 in A review of cathodic protection-A literature survey (Houston, TX: NACE)

Uusitalo E 1961 Corrosion 1767

Uusitalo E 1966 Second int. conf. on metallic corrosion, Houston, TX, p. 812 